\title{
Extending the Postpartum Anovulatory Period in Dairy Cattle with Estradiol Cypionate
}

\author{
J. M. Haughian, ${ }^{\star}$ R. Sartori, $†$ J. N. Guenther, $\dagger$ A. Gümen, $\dagger$ and M. C. Wiltbank ${ }^{\star} \dagger$ \\ *Endocrinology-Reproductive Physiology Program and \\ †Department of Dairy Science, \\ University of Wisconsin, \\ Madison, WI 53706
}

\begin{abstract}
Estradiol cypionate (ECP), a long-acting estrogen, has been used therapeutically in early postpartum (PP) dairy cows. In experiment 1 , effects of ECP on circulating reproductive hormones, cyclicity, and ovarian function in early PP dairy cows were investigated. Lactating Holsteins received $10 \mathrm{mg}$ of ECP (ECP; $\mathrm{n}=17$ ) or placebo $(\mathrm{CON} ; \mathrm{n}=16)$ on $\mathrm{d} 7 \mathrm{PP}$. Serum and ultrasound data were acquired from 5 to $90 \mathrm{~d}$ of lactation. Compared to CON, ECP cows had greater serum estradiol for $10 \mathrm{~d}$ and lower serum FSH for $15 \mathrm{~d}$ posttreatment. After ECP, the appearance of follicles $\geq 10 \mathrm{~mm}$ and time to first ovulation were delayed. Nevertheless, by $90 \mathrm{~d}$ PP, normal estrous cycles were found in only $50 \%$ of CON versus $88 \%$ of ECP cows. Primiparous, but not multiparous, cows receiving ECP had higher milk yields. Experiment 2 investigated effects of ECP on reproduction and milk production on a commercial dairy. Cows were blocked by parity and randomized to three treatments: $0(\mathrm{n}=85), 4(\mathrm{n}=85)$, or $10(\mathrm{n}=86)$ $\mathrm{mg}$ of ECP on d 5 to 8 PP. Data included cycling status (two ultrasound examinations at 30 to $33 \mathrm{~d} \mathrm{PP}$ and 7 $\mathrm{d}$ later), individual reproduction records, and daily milk yields from 10 to $90 \mathrm{~d}$ PP. In primiparous cows, ECP had no significant effects on ovulatory status or milk yields. By $40 \mathrm{~d}$ PP, a greater percentage of multiparous cows receiving $10 \mathrm{mg}$ of ECP remained anovulatory compared with those receiving 0 or $4 \mathrm{mg}$. Milk yields were highest for multiparous cows receiving $4 \mathrm{mg}$ of $\mathrm{ECP}$, intermediate for the 10-mg dose, and lowest for controls. Lower conception was observed in multiparous cows receiving $4 \mathrm{mg}$ of ECP. In summary, ECP delayed time to first ovulation particularly in multiparous cows, an effect associated with observed inhibition of circulating FSH. Milk yield responses to ECP were inconsistent within parity groups across the two experiments.
\end{abstract}

Received January 29, 2002.

Accepted August 6, 2002.

Corresponding author: M. C. Wiltbank; e-mail: wiltbank@calshp. cals.wisc.edu.
(Key words: estradiol cypionate, anovulation, milk yield, dairy cattle)

Abbreviation key: $\mathbf{C L}=$ corpus luteum, $\mathbf{C O N}=$ control, DA = displaced abomasum, ECP = estradiol cypionate, $\mathbf{P P}=$ postpartum.

\section{INTRODUCTION}

Data on the relationship between postpartum (PP) anovulatory interval and dairy cattle reproduction are in conflict. For example, Smith and Wallace (1998) reported that increased time to first ovulation ultimately shortened the interval from calving to conception, reduced the number of services per cow, and improved conception rates. Similarly, Opsomer et al. (2000) reported that later PP resumption of ovarian cyclicity was associated with a reduced risk for prolonged luteal cycles before first service. Despite these reports indicating that a later resumption of $\mathrm{PP}$ ovarian cyclicity is beneficial, some studies are consistent with the idea that early resumption of cyclicity is most beneficial to dairy cow fertility (Thatcher and Wilcox, 1973; Lucy et al., 1992; Darwash et al., 1997). Specifically, Darwash et al. (1997) reported that early resumption of $\mathrm{PP}$ ovarian activity reduced the interval to first service and improved conception rates. Additionally, Lucy et al. (1992) reported that cows ovulating earlier PP had fewer services per conception and a shorter calving to conception interval. Unfortunately, these correlative studies provide results that can be confounded. For example, some causes of longer PP anovulatory intervals (e.g., health problems, negative energy balance) may directly impair reproduction (Butler et al., 1981; Butler and Smith, 1989; Lucy et al., 1992), whereas a delayed time to first ovulation may positively influence other reproductive factors such as uterine environment (Smith and Wallace, 1998). The present study was designed to artificially extend the PP anovulatory interval using a single PP treatment with estradiol cypionate (ECP, Pharmacia Animal Health, Kalamazoo, MI). This long-acting estrogen has been approved by the FDA for treating uterine and PP disorders in cattle. Recently, ECP has been used extensively to treat early PP dairy 
cows (Upham, 1997) or in reproductive synchronization programs (Thundathil et al., 1998; Pancarci et al., 2002).

The first experiment was an intensive evaluation of a limited number of cows to provide information on the hormonal and ovarian morphology following a single treatment with ECP at $7 \mathrm{~d}$ PP. We hypothesized that treating cows with $10 \mathrm{mg}$ of ECP would increase the time to first ovulation by altering ovarian follicular dynamics. We speculated that ECP could delay the first ovulation by inhibiting FSH and delaying the onset of PP follicular waves. Alternatively, lactating cows could develop anovulatory follicular cysts in response to ECP based on previous results from our laboratory, indicating that follicular cysts can be induced by a single estradiol benzoate injection (Gümen et al., 2002). In addition to reproductive implications, we were also interested in evaluating the effect of ECP on milk production. Estrogens have been shown to be capable of inducing epithelial proliferation in mixed cultures of mammary epithelium and stromal cells (Tucker, 2000), an effect that appears to be mediated through a series of growth factors produced in the mammary stromal tissue (Woodward et al., 1998; Akers et al., 2000). Progesterone, on the other hand, has been implicated as antilactogenic (Tucker, 2000). Nevertheless, estrogens could have negative effects on mammary tissue (Athie et al., 1996), particularly in the presence of progesterone. We hypothesized that ECP would increase milk production by creating a predominantly estrogenic endocrine environment without the presence of progesterone, due to a delay in time to first ovulation. Our observations from the first experiment suggested that ECP treatment was capable of delaying the time to first PP ovulation with potentially beneficial effects on reproduction and milk production. Consequently, a second experiment involving a greater number of cows was performed to test for an effect of ECP on both reproductive efficiency and milk production.

In general, a 4-mg dose of ECP has been recommended for treatment of lactating dairy cows; however, we speculated that a greater dose might be required to extend the time to first ovulation. A recent study using lactating dairy cows in a commercial dairy in California found no significant effect of $4 \mathrm{mg}$ of ECP on abnormal uterine diagnosis on 27 to $40 \mathrm{~d} \mathrm{PP}$, days to first $\mathrm{AI}$, or pregnancy rate to the first AI (Wagner et al., 2001). However, that study did not evaluate the time to first ovulation or milk production, and only the single 4-mg dose of ECP was tested. Therefore, our second experiment evaluated the effect of two doses of ECP (4 or $10 \mathrm{mg}$ ) versus no treatment in lactating dairy cows in a commercial dairy. The hypothesis being tested was that an early PP treatment with a high dose of ECP would extend the PP anovula- tory interval and improve reproductive efficiency and milk production.

\section{MATERIALS AND METHODS}

\section{Experiment 1}

Animals. Lactating dairy cows (17 multiparous and 16 primiparous) were treated with either sesame oil (CON group), or $10 \mathrm{mg}$ of ECP (ECP group) on d 7 PP. All cows calved over a period beginning in May and ending in July of 1999 and were housed and managed at the University of Wisconsin-Madison Dairy Cattle Research Center. Cows were milked twice a day, and individual milk production records were acquired using Dairy Comp 305 (Valley Agricultural Software, Tulare, CA). A voluntary waiting period of $90 \mathrm{~d}$ was defined before initiation of the trial, and cows were started on the Ovsynch timed-AI protocol: GnRH (100 $\mu \mathrm{g}$; Cystorelin, Merial Limited, Athens, GA) - 7 d - PGF $_{2 \alpha}$ (25 mg; Lutalyse, Pharmacia \& Upjohn Co., Kalamazoo, MI) - 2 d GnRH - $18 \mathrm{~h}$ - timed AI (Pursley et al., 1995) following this period. Intensive data collection was discontinued $1 \mathrm{~d}$ after timed insemination.

Ultrasonography and blood sampling. Ovarian follicular and luteal activity were monitored by transrectal ultrasonography using an Aloka-500 ultrasound machine equipped with a $7.5-\mathrm{MHz}$ linear array transducer (Corometrics Medical Systems, Inc., Wallingford, CT). Primiparous cows were scanned every other day from d 5 until the end of the trial period. Multiparous cows were scanned daily from d 5 until d 30 PP and then every other day until the end of the trial period. Blood sampling was performed daily from d 5 PP until the end of the trial period. All cows were bled via coccygeal venipuncture using vacutainer collection tubes (Becton, Dickinson, and Company, Franklin Lakes, NJ). Blood samples were refrigerated for $24 \mathrm{~h}$, centrifuged at room temperature for $15 \mathrm{~min}$, and serum was collected and frozen at $-20^{\circ} \mathrm{C}$ until hormone assays. Intervals (days) to first ovulation were determined by ultrasonography and subsequently confirmed by determination of serum progesterone concentrations using an ELISA procedure described previously (Rasmussen et al., 1996). The time of first ovulation recorded by ultrasonography was confirmed if serum progesterone levels remained below 0.5 $\mathrm{ng} / \mathrm{ml}$ before, and then increased to levels $\geq 0.5 \mathrm{ng} / \mathrm{ml}$ after detection of ovulation. Inter- and intraassay coefficients of variation were 7.4 and $7.1 \%$, respectively. Serum estradiol concentrations were evaluated by radioimmunoassay (Kulick et al., 1999) for all cows on d 8 PP to ensure correct treatment allocation. Additionally, serum estradiol concentrations were determined for a randomly selected group of six ECP and six CON cows every other day from d 6 until d 24 PP. Inter- and intraassay coeffi- 
cients of variation, calculated from a pooled quality control sample with an average concentration of $2.2 \mathrm{pg}$ estra$\mathrm{diol} / \mathrm{ml}$, were 13.8 and $10.2 \%$, respectively. As a percentage of maximum binding, the amount of tracer bound was reduced by 10 and $90 \%$ at standard concentrations of 0.32 and $40.00 \mathrm{pg}$ estradiol $/ \mathrm{ml}$, respectively. Plasma FSH was measured by radioimmunoassay as previously described (Bolt and Rollins, 1983; Bolt et al., 1990) using the primary antibody NIDDK-anti-oFSH-I-2 and the radiolabeled and standard antigen USDA-bFSH-I-2. Three assays were conducted with quality control samples in each assay. Inter- and intraassay coefficients of variation, calculated from pooled quality control samples averaging 0.28 and $0.12 \mathrm{ng}$ of $\mathrm{FSH} / \mathrm{ml}$, were 8.7 and $6.9 \%$, respectively. As a percentage of maximum binding, the amount of tracer bound was reduced by 10 and $90 \%$ at standard concentrations of 0.03 and $5.00 \mathrm{ng}$ of FSH/ $\mathrm{ml}$, respectively.

Follicular waves and cyclic status. For the purpose of analyzing ultrasound data, a follicular wave was defined as a cohort of follicles from which a dominant follicle emerged. A dominant follicle was defined as a follicle that attained a diameter $\geq 10 \mathrm{~mm}$, as this size is associated with acquisition of $\mathrm{LH}$ responsiveness (Crowe et al., 2000; Sartori et al., 2001). Emergence of the first posttreatment dominant follicle was defined as the day on which a follicle $\geq 10 \mathrm{~mm}$ was observed after treatment. Follicular waves before ovulation and the follicular wave terminating with ovulation of the dominant follicle were considered when tabulating the number of waves observed before ovulation. Day 0 of the estrous cycle was defined as the day on which the ovulatory follicle(s) was last detected by ultrasound. The first interovulatory interval was defined to be the duration of time between $d$ 0 of the first and second estrous cycles.

To aid in comparison of the reproductive status near the time of breeding, the reproductive status of each cow was evaluated in retrospect from d $90 \mathrm{PP}$ (beginning of Ovsynch) and characterized as either normal or abnormal. Cows considered to have a normal reproductive status were those not exhibiting one of three anovulatory conditions including: anovulation, ovulation followed by no ovulation, or persistent corpus luteum (CL). Anovulation was defined as no ovulation for the entire 90 -d period before Ovsynch. Ovulation followed by no ovulation was classified as a cow that ovulated and then failed to ovulate the dominant follicle present at the time of CL regression. Persistent CL was defined as a luteal structure that remained detectable on the ovary for $>30 \mathrm{~d}$ and maintained serum progesterone concentrations $>1 \mathrm{ng} /$ $\mathrm{ml}$ (adapted from Bulman and Lamming, 1977).

\section{Experiment 2}

Animals. This trial was conducted on a 1200-cow commercial dairy farm in southern Wisconsin and included primiparous and multiparous cows that calved between May and August 2000. Visits to the farm occurred twice per week for administering treatments and collecting data. Cows between 5 and $8 \mathrm{~d}$ PP were blocked by previous lactation number $(0$ or $\geq 1)$ and randomly assigned to one of three treatment groups: untreated control $(0$ mg; $\mathrm{n}=54$ primiparous and 31 multiparous), $4 \mathrm{mg}$ of ECP ( $\mathrm{n}=52$ primiparous and 33 multiparous), and 10 $\mathrm{mg}$ of $\mathrm{ECP}$ ( $\mathrm{n}=54$ primiparous and 32 multiparous). Disproportionately more primiparous cows were available for use in the study because the dairy farm had purchased pregnant heifers to expand the herd. All cows were housed in a free-stall facility and milked three times a day. Herd personnel were responsible for reproductive management including heat detection and AI. The herd reproduction program involved a 50-d voluntary waiting period after which cows were inseminated at estrus. Cows were determined to be in estrus by visual observation of standing heat or activation of a pedometer-linked detection system. Primiparous cows that were anovulatory at $\mathrm{d} 40 \mathrm{PP}$, or displayed a prolonged period since last detected heat, were bred using Ovsynch after $50 \mathrm{~d}$ PP. Multiparous cows that failed to show estrus or displayed a prolonged period since last detected heat were also bred by Ovsynch, but these tended to occur after $\sim 100 \mathrm{~d}$ PP. Herd managers and herd veterinarian were blind to treatment.

Data Collection. Ultrasonography was used to evaluate the presence of CL and the size of follicles on the ovary at 30 to $33 \mathrm{~d}$ PP. A follow-up examination was performed $7 \mathrm{~d}$ later only for cows that displayed no CL at the previous examination. It should be noted that a percentage of cows could not be evaluated due to death, culling, or failure to sort the cows from the main milking herd at the facility. Anovulatory cows were determined by the absence of luteal tissue at both ultrasound examinations. Daily milk yield (until $90 \mathrm{~d} P \mathrm{PP}$ ) and reproduction and health records (until $200 \mathrm{~d}$ PP) for each cow were collected on Dairy Comp 305.

\section{Statistical Analyses}

In experiments 1 and 2, comparisons between treatment groups in days to detection of the first dominant follicle, days to first ovulation, size of ovulatory follicles, ovulations before $90 \mathrm{~d} \mathrm{PP}$, days to first service, and days to conception were compared using the ANOVA procedure in SAS (SAS, 1998). Binomial data in experiments 1 and 2 , such as the proportion of cows cycling normally or proportion anovulatory, were compared by chi-square using the FREQ procedure in SAS, and $P$ values were determined using Fisher's exact test. For comparison across multiple-parity groups and treatments, binomial 
data were analyzed by the LOGISTIC procedure in SAS. Significant terms included in the model (parity, treatment, or parity $\times$ treatment interaction) were determined using a backward selection procedure at $\propto=0.05$.

Least squares means daily milk yield values for experiments 1 and 2 were analyzed using the MIXED procedure in SAS with the following model: $\mathbf{Y}_{\mathrm{ijkl}}=\mu+\alpha_{\mathrm{i}}+\beta_{\mathrm{j}}$ $+\gamma_{\mathrm{k}}+\delta_{\mathrm{l}}+(\alpha \beta)_{\mathrm{ij}}+(\alpha \delta)_{\mathrm{ijl}}+\mathrm{e}_{\mathrm{ijklm}}$, where $\mathrm{Y}_{\mathrm{ijkl}}=$ dependent variable (milk yield); $\mu=$ overall population mean; $\alpha_{\mathrm{i}}=$ effect of block (parity, $\mathrm{i}=2$ ); $\beta_{\mathrm{j}}=$ effect of treatment $(\mathrm{j}=$ $3) ; \gamma_{\mathrm{k}}=$ time effect (DIM); $\delta_{1}=$ effect of displaced abomasum (DA); $(\alpha \beta)_{\mathrm{ij}}=$ interaction of treatment and parity terms; $(\alpha \delta)_{\mathrm{ijl}}=$ interaction of treatment and DA terms; $\mathrm{e}_{\mathrm{ijkl}}=$ residual error term. Means were compared within SAS using the Tukey method for multiple means comparison. Estradiol and FSH profiles were also analyzed by the MIXED procedure using a similar model; however, the DA and DA $\times$ treatment interaction terms were not included in the model. Based upon the Akaike's information criterion, covariance parameters were estimated using the autoregressive- 1 model. All effects in each model, other than the main effect of treatment $(P=0.079)$ for milk yield, were selected based on the criterion that each was significant at $P<0.05$.

The EXPAND procedure in SAS was used to calculate area under the curve of the hormone profiles. Survivalcurve analysis of days to conception in experiment 2 was performed using the LIFETEST procedure in SAS. Significant differences in survival curve profiles were determined using the log-rank test statistic.

\section{RESULTS}

\section{Experiment 1}

Figure 1 illustrates the mean serum estradiol and FSH profiles observed in a sample of multiparous and primiparous ECP and CON cows. Treatment with ECP on $\mathrm{d} 7 \mathrm{PP}$ increased serum estradiol concentrations with differences $(P<0.01)$ evident from d 8 until d 16 PP. There was a significant effect of treatment and treatment $\times$ time interaction (Figure 1a). Mean area under the curve for individual serum estradiol concentration profiles was greater $(P<0.01)$ in ECP-treated $(64.1 \pm$ 8.5 arbitrary units) compared with control (5.36 \pm 3.14 arbitrary units) cows. Treatment with ECP reduced ( $P$ $<0.05)$ serum FSH concentrations to less than half the concentrations observed before treatment or those observed in control cows (Figure 1b). Lower concentrations of FSH were detected on $\mathrm{d} 8$ and 10 at $P<0.01$, and d $9,11,15$, and 16 at $P<0.05$. Mean area under the curve for individual serum FSH concentration profiles was reduced $(P<0.05)$ in ECP-treated $(4.74 \pm 0.23$ arbitrary units) compared with control $(6.91 \pm 0.82$ arbitrary units) cows.
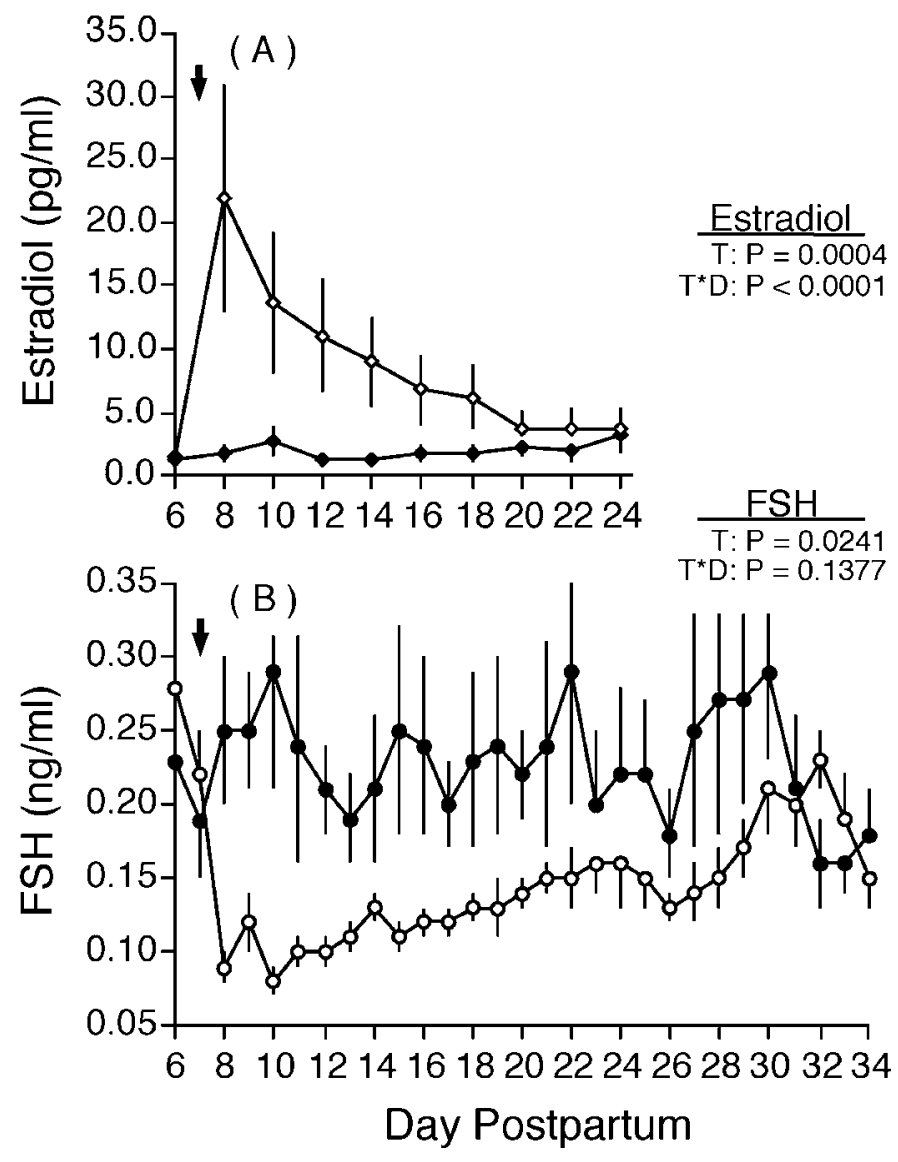

Figure 1. Mean $( \pm \mathrm{SEM})$ serum concentrations of estradiol; ((CON $=$ solid diamond, estradiol cypionate $(\mathrm{ECP})=$ open diamond $)$ and FSH; CON = solid circle, ECP = open circle) from randomly selected multiparous and primiparous ECP and CON cows $(n=6$ per treatment). The arrow represents day of treatment (d $7 \mathrm{PP}) . P$ values represent significance of effects $(\mathrm{T}=$ treatment, $\mathrm{T} * \mathrm{D}=$ treatment $\times$ day interaction).

Figure 2a depicts the ovarian and FSH profiles of CON cow \#4503 that are representative of normal profiles from CON cows. There were surges in FSH about every $10 \mathrm{~d}$ associated with emergence of each follicular wave. In contrast, a representative ECP-treated cow, \#4396 (Figure 3a), had a suppression of FSH surges after ECP treatment and a delay in follicular waves. However, there was substantial variability in the response to ECP. Cow \#4212 (Figure 3b) resumed follicle growth and ovulated shortly after treatment; whereas cow \#4334 (Figure 3c) had a 40-d delay before the next follicular wave and a 70-d delay before the first ovulation. On average, the time to detection of the first dominant follicle (follicle $\geq 10 \mathrm{~mm})$ was greater $(P<0.01)$ in ECP compared with CON (Table 1); however, the number of follicular waves observed before first ovulation was similar. The average time to first ovulation was greater $(P<0.01)$ by nearly $20 \mathrm{~d}$ in ECP (range: 32 to $80 \mathrm{~d}$ ) vs. CON (range: 14 to 
E
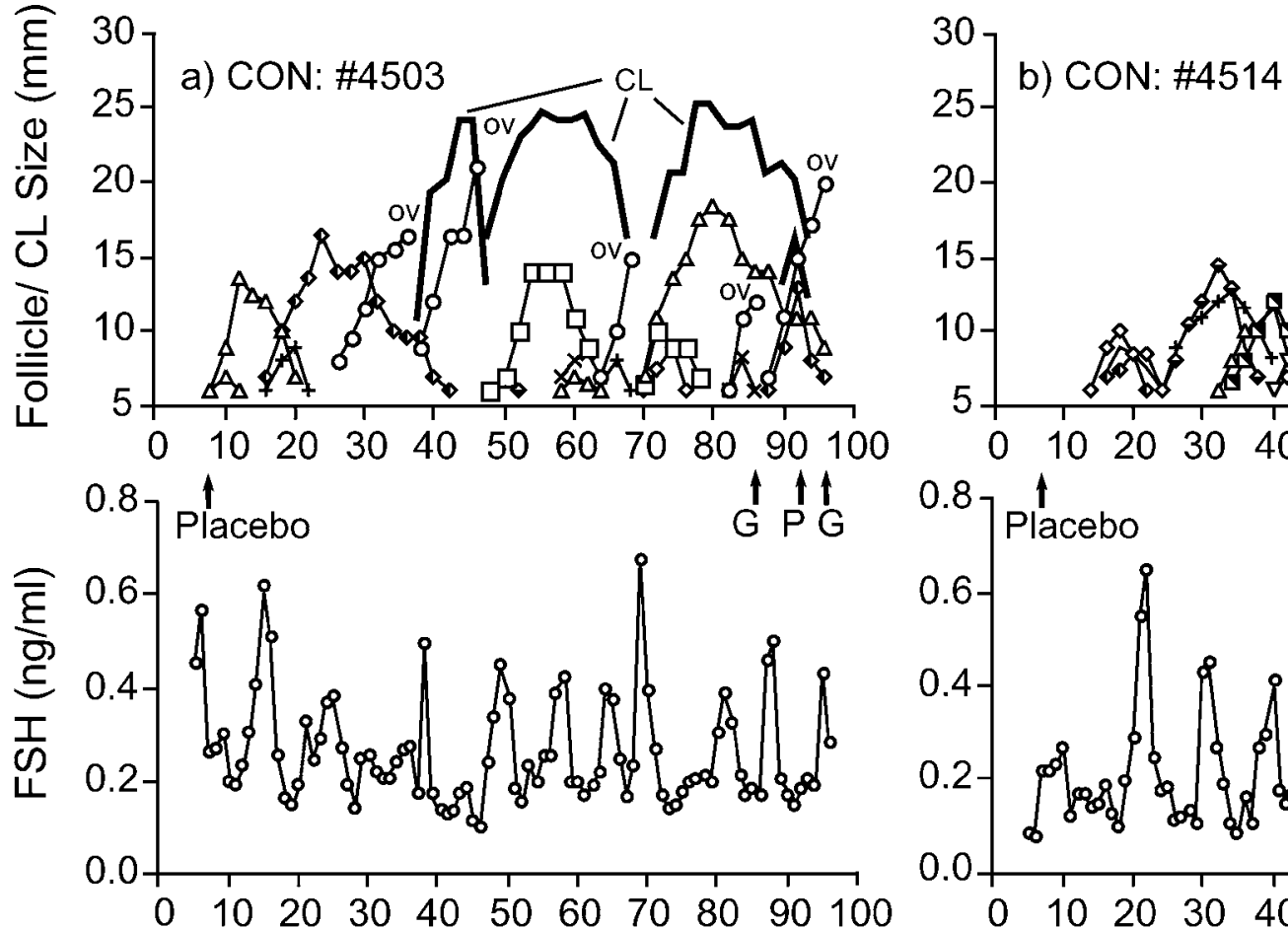

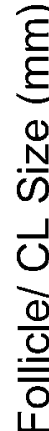
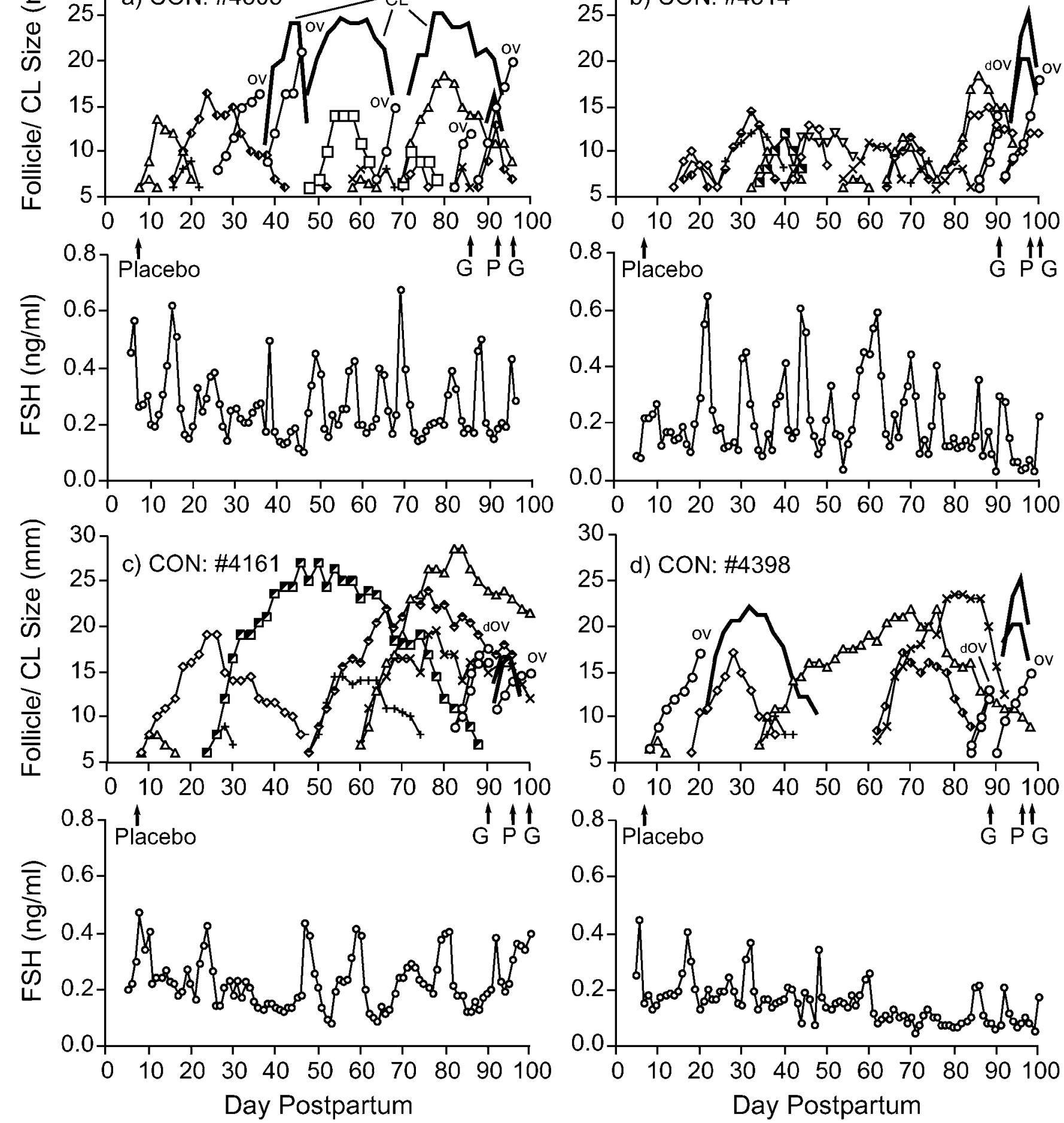

Figure 2. Individual ovarian and FSH profiles from CON cows treated with placebo at 7 d postpartum (PP) (experiment 1). Primiparous cow \#4503 is representative of the typical ovarian profile observed in CON cows. Primiparous cow \#4514 and multiparous cow \#4161 represent cows displaying a small follicle and large follicle anovulatory condition, respectively. Multiparous cow \#4398 is representative of individuals that ovulated but then failed to ovulate again after regression of the CL. In the ovarian profiles, open circles and solid bold lines represent ovulatory follicles and $\mathrm{CL}$, respectively. $\mathrm{OV}=$ ovulation, $\mathrm{dOV}=\mathrm{double}$ ovulation, $\mathrm{G}=\mathrm{GnRH}, \mathrm{P}=\mathrm{PGF} / 2$. 


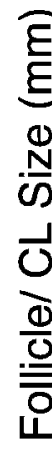
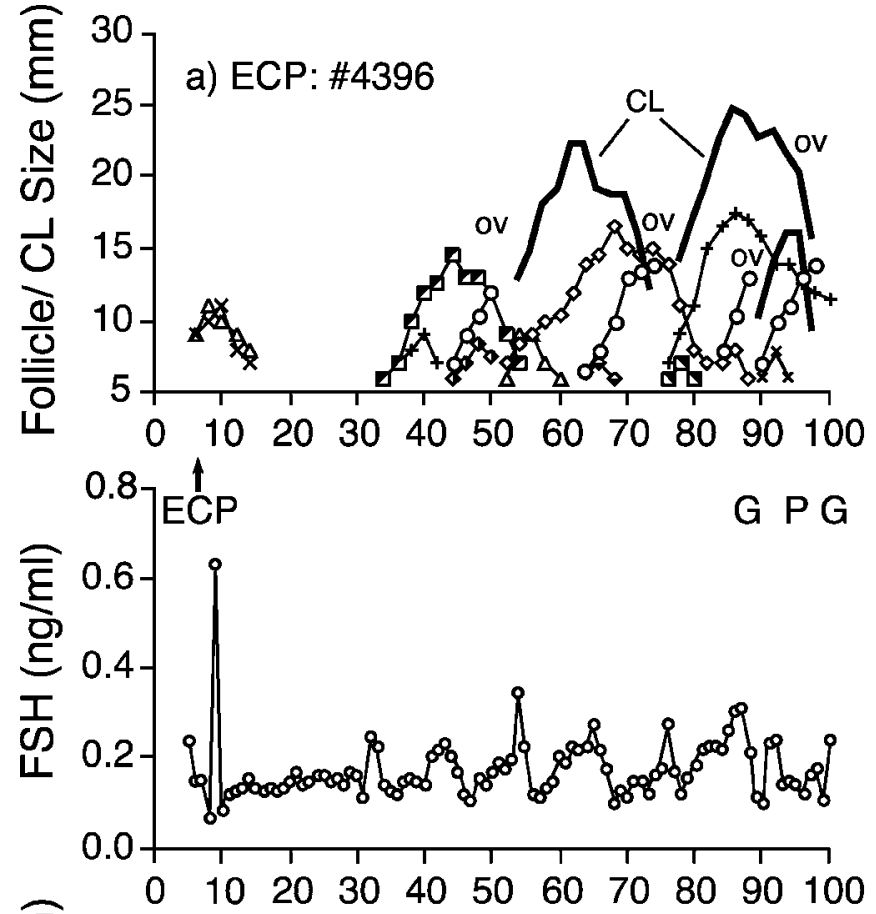

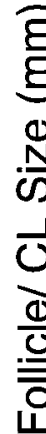

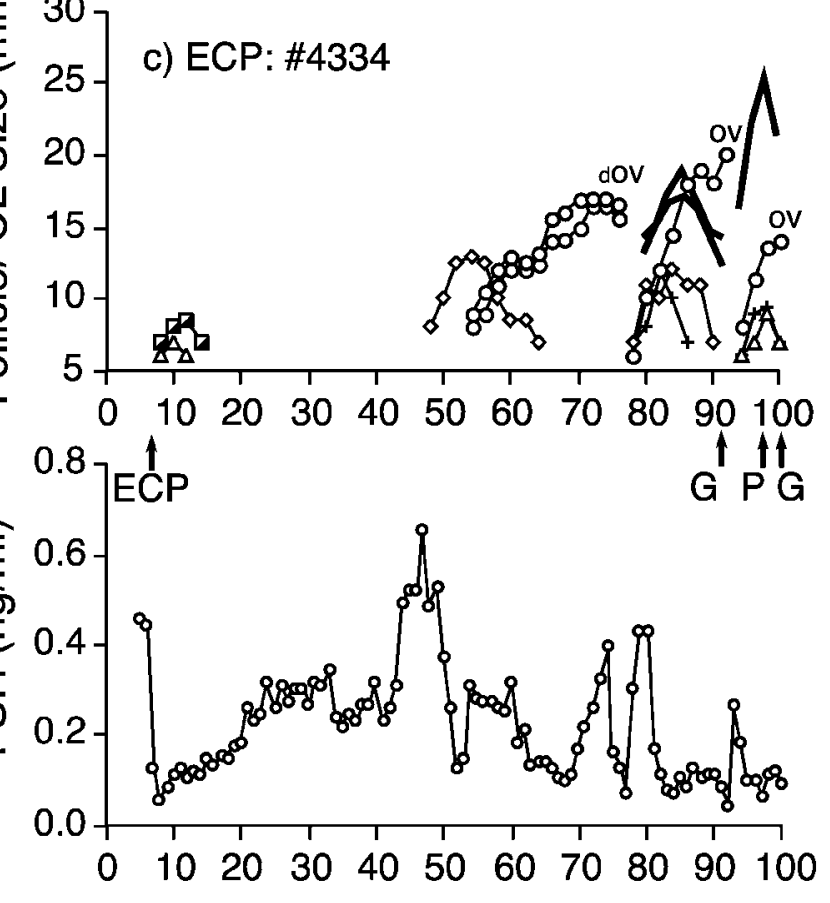

Day Postpartum

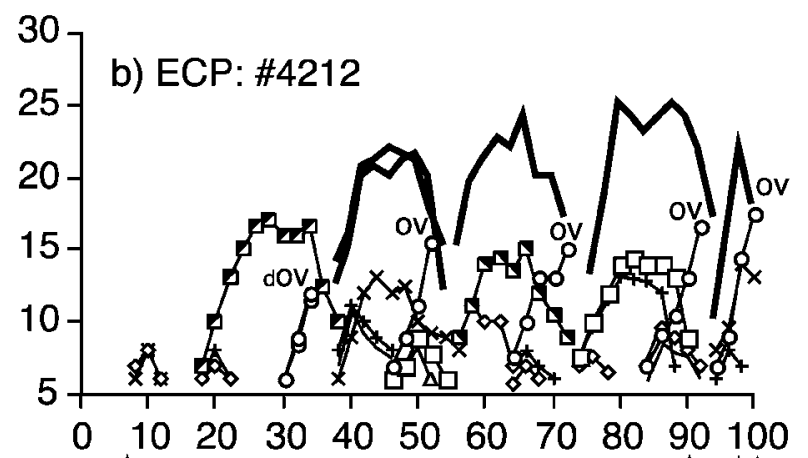

0.

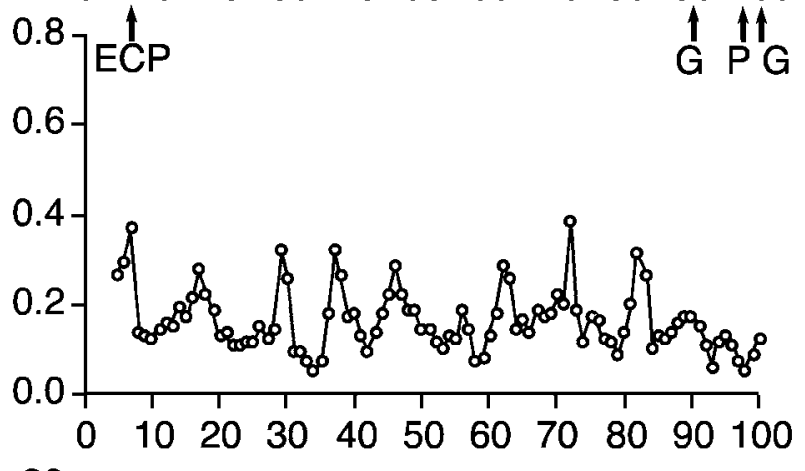

30.7 d) ECP: \#3966
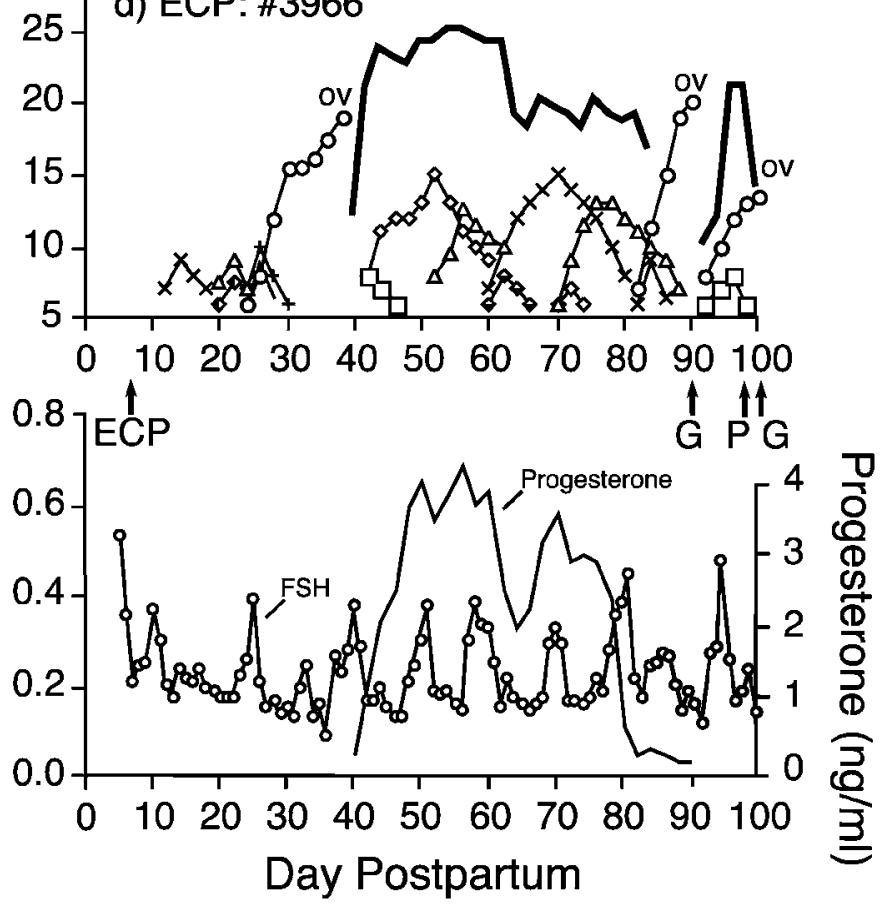

Figure 3. Individual ovarian and FSH profiles from cows treated with ECP (10 mg) at $7 \mathrm{~d}$ PP (experiment 1). Multiparous cow \#4396 represents the typical ovarian profile observed in ECP-treated cows. Multiparous cows \#4212 and \#4334 represent variation in time to first ovulation observed in ECP-treated cows. Multiparous cow \#3966 is representative of cows with ovulation followed by development of a persistent CL ( $>1 \mathrm{ng} / \mathrm{ml}$ progesterone for $>30 \mathrm{~d})$. In the ovarian profiles, open circles and solid bold lines represent ovulatory follicles and $\mathrm{CL}$, respectively. $\mathrm{OV}=$ ovulation, $\mathrm{dOV}=$ double ovulation, $\mathrm{G}=\mathrm{GnRH}, \mathrm{P}=\mathrm{PGF}_{2 \alpha}$. 
Table 1. Summary of experimant 1 results comparing the effect of $10 \mathrm{mg}$ of estradiol cypionate (ECP) or placebo administered d 7 postpartum (PP) on follicular dynamics before and after first ovulation, and reproductive status at the time of breeding, d $90 \mathrm{PP}$.

\begin{tabular}{|c|c|c|c|}
\hline End point & $\mathrm{CON}$ & ECP & Probability \\
\hline \multicolumn{4}{|l|}{ Days to detection of (mean \pm SEM) } \\
\hline Follicle $\geq 10 \mathrm{~mm}$ & $12.3 \pm 3.0$ & $29.1 \pm 7.1$ & 0.0002 \\
\hline First ovulation & $35.8 \pm 4.5$ & $55.6 \pm 4.1$ & 0.003 \\
\hline $\begin{array}{l}\text { Preovulatory follicular waves; no. } \\
\text { (mean } \pm \text { SEM) }\end{array}$ & $2.6 \pm 0.6$ & $3.0 \pm 0.7$ & 0.45 \\
\hline \multicolumn{4}{|l|}{ Cows ovulating before $(\%)$} \\
\hline Day $30 \mathrm{PP}$ & 38 & 0 & 0.0072 \\
\hline Day 50 PP & 69 & 35 & 0.084 \\
\hline Day $90 \mathrm{PP}$ & 81 & 94 & 0.17 \\
\hline $\begin{array}{l}\text { Size of first ovulatory follicle; } \mathrm{mm} \\
(\text { mean } \pm \text { SEM })\end{array}$ & $15.7 \pm 3.9$ & $14.6 \pm 3.5$ & 0.30 \\
\hline $\begin{array}{l}\text { Ovulations prior to } 90 \mathrm{~d} \text { PP; no. } \\
\text { (mean } \pm \text { SEM) }\end{array}$ & $2.4 \pm 0.3$ & $1.8 \pm 0.2$ & 0.082 \\
\hline \multicolumn{4}{|l|}{ Days from first to second ovulation (\%) } \\
\hline 16 to 24 & 38 & 62 & 0.27 \\
\hline$\geq 25$ & 23 & 13 & 0.63 \\
\hline Normal reproductive status, $\sim 90 \mathrm{~d}$ PP (\%) & 50 & 88 & 0.026 \\
\hline
\end{tabular}

$72 \mathrm{~d}$; Table 1). Only cows that ovulated before the first injection of GnRH at $90 \mathrm{~d} \mathrm{PP}(16 \mathrm{ECP}$ and $13 \mathrm{CON}$ ) were considered in this analysis. A difference in days to first ovulation was evident regardless of parity: multiparous (CON: $38.3 \pm 7.4 \mathrm{~d}$, ECP: $55 \pm 5.5 \mathrm{~d} ; P<0.10)$ and primiparous (CON: $33.0 \pm 5.3 \mathrm{~d}$, ECP: $56.7 \pm 6.7 \mathrm{~d} ; P<$ $0.05)$. There were significant differences in the percentage of cows that had ovulated by $d 30$ and 50 , but this difference was no longer evident by d 90 PP (Table 1). There was no evidence $(P>0.10)$ to suggest that parity influenced the percentage of cows ovulating before 30 or $50 \mathrm{~d}$ PP. There was no difference between ECP and CON in mean diameter of the first ovulatory follicle or in the interval between first and second ovulation (Table 1).

When the reproductive status of each animal was examined at $90 \mathrm{~d} \mathrm{PP}$, the incidence of abnormal ovarian cyclicity was greater $(P<0.05)$ in $\mathrm{CON}(50 \%)$ than in ECP (12\%) cows. Abnormal cyclicity was attributed to three different anovulatory conditions. The first form of anovulation, observed in three CON and one ECP cow, was characterized by the absence of ovulation from parturition to the first GnRH treatment in the Ovsynch protocol at $\sim 90 \mathrm{~d}$ PP. Two of these cows (both CON) had follicular growth similar to that represented by cow \#4514 (Figure 2b). In this cow, there were multiple anovulatory follicular waves, each preceded by an FSH surge, but the maximal size of the dominant follicle was less than ovulatory size $(15 \mathrm{~mm}$; see Wiltbank et al., 2002). The other persistently anovulatory CON cow \#4161 (Figure 2c) fits the classical definition of a cystic cow put forth by Kesler and Garverick (1982) due to the appearance of large follicles $>25 \mathrm{~mm}$ in diameter that persisted for $>10 \mathrm{~d}$ in the absence of a CL. The anovulatory ECP cow (profile not shown) had multiple follicular waves with dominant follicles that grew to a maximum diameter of only $20 \mathrm{~mm}$. Three CON cows displayed a second form of anovulation resembling that of CON cow \#4398 (Figure 2d). These cows had a normal ovulation, but then failed to ovulate again despite regression of the CL. Time spent in this anovulatory condition, calculated from day of ovulation at the start of the extended cycle, ranged from 46 to $70 \mathrm{~d}$. The final form of abnormal ovarian cyclicity was a persistent CL that was observed in two CON and one ECP cow. Figure 3d depicts the ovarian morphology, FSH, and progesterone profile of a representative cow (ECP; \#3966) displaying a persistent CL.

There was a high incidence of DA in primiparous cows before $30 \mathrm{~d}$ PP with two of seven ECP and five of seven CON primiparous cows having a DA. Only one ECP and two CON multiparous cows were treated for DA. The least squares means of daily milk yield from 10 to 90 d PP were not different between treated and control multiparous cows; however, primiparous cows treated with ECP had greater milk production $(P<0.01)$ than untreated cows (Table 3).

\section{Experiment 2}

Analysis of the percentage of cows with a CL at d 30 PP using the LOGISTIC procedure provided evidence for an effect $(P<0.05)$ of treatment, parity, and treatment-by-parity interaction. Chi-square analysis indicated that there were no differences $(P>0.10)$ in the percentage of primiparous cows with a CL at d $30 \mathrm{PP}$ (Table 2). In contrast, there was a significant effect of ECP treatment on percentage of multiparous cows with a detectable CL at d 30 PP (Table 2). Only $24 \%$ of multip- 
arous cows treated with $10 \mathrm{mg}$ of ECP had a CL compared with $67 \%$ of untreated cows $(P<0.01)$. At the second ultrasound examination conducted $7 \mathrm{~d}$ later, the LOGISTIC procedure provided evidence for an effect ( $P$ $<0.05$ ) of treatment on the proportion of anovulatory (no CL detected at either examination) cows. The percentage of anovulatory, primiparous cows was not different $(P>0.10)$ among treatments (Table 2$)$; however, in multiparous cows, anovulation at $\sim 40 \mathrm{~d}$ PP was more prevalent in cows treated with $10 \mathrm{mg}$ of ECP compared with $0 \mathrm{mg}(P<0.05$; Table 2$)$. Analysis of breeding records indicated that the average days to first service was not different $(P>0.10)$ among all treatment groups (Table 2) and that the average days to conception was greater $(P<0.10)$ in multiparous cows treated with 4 mg than $10 \mathrm{mg}$ of ECP (Table 2). Despite this apparent difference in average days to conception using ANOVA, there was no effect $(P>0.10)$ of ECP treatment on days to conception using the more appropriate survival curve analysis (Figure 4). In primiparous cows, first-service conception rate was not different $(P>0.10)$ between cows treated with $0(22.7 \%, \mathrm{n}=46), 4(22.9 \%, \mathrm{n}=49)$, or 10 $(22.2 \%, \mathrm{n}=48) \mathrm{mg}$ of ECP. Similarly, the conception rate for all services did not differ $(P>0.10)$ between primiparous cows treated with $0(24.0 \%, \mathrm{n}=154), 4$ $(25.3 \%, \mathrm{n}=154)$, or $10(26.1 \%, \mathrm{n}=153) \mathrm{mg}$ of ECP. In multiparous cows, the first-service conception rate for cows treated with $0 \mathrm{mg}$ of ECP tended to be greater $(P$ $<0.10)$ than the rate for cows treated with $4 \mathrm{mg}$ (36.0 vs. $12.5 \%, \mathrm{n}=27$ for each group); however, there was no difference $(P>0.10)$ between 0 and $10 \mathrm{mg}$ of ECP ( 36.0 vs. $24 \%, \mathrm{n}=27$ and 29 , respectively). Across all services, the overall conception rate in multiparous cows treated with $0 \mathrm{mg}$ of ECP $(30.0 \%, \mathrm{n}=70)$ was greater $(P<0.05)$ than that for cows treated with $4 \mathrm{mg}$ of ECP $(14.4 \%, \mathrm{n}=90)$. No differences $(P>0.10)$ in overall conception rate were detected between multiparous cows treated with 0 or $10 \mathrm{mg}$ of ECP (30.0 vs. $21.6 \%, \mathrm{n}=70$ and 88 , respectively).

There were significant effects of treatment and treatment $\times$ parity interaction on milk production from 10 to $90 \mathrm{~d}$ PP (Table 3). In primiparous cows, there were no differences in average daily milk yield between groups (Table 3). In multiparous cows, the 4-mg treatment group had greater $(P<0.01)$ milk production than either the 0 or $10 \mathrm{mg}$ treatment groups (Table 3). A higher yield was also evident in $10-\mathrm{mg}$ compared with $0-\mathrm{mg}$ treatments for multiparous cows $(P<0.05$; Table 3$)$. In retrospect, a comparison of first-lactation 305-d milk yields for multiparous cows provided no indication $(P>$ 0.10 ) of a predisposition for higher milk yield (mean \pm SEM) in 0- $(11,100 \pm 280 \mathrm{~kg}), 4-(11,354 \pm 298 \mathrm{~kg})$, or 10 -mg $(11,700 \pm 264 \mathrm{~kg})$ ECP-treated cows. Figure 5 illustrates the profile of daily milk yield averages at 5d intervals for all treatment groups.

Table 4 shows the differences between ECP treatment groups in selected animal health measures for both primiparous and multiparous cows. The percentage of cows culled before $200 \mathrm{~d}$ PP was similar among all groups. The incidence of DA was not different among groups; however, the incidence of mastitis tended to be greater $(P<0.10)$ in primiparous cows treated with 10 mg compared with $0 \mathrm{mg}$ of ECP (Table 4).

Table 2. Experiment 2 results showing reproductive status, days to first service, and days to conception for primiparous and multiparous cows treated with 0,4 , or $10 \mathrm{mg}$ of estradiol cypionate (ECP) on d 5 to 8 postpartum (PP)

\begin{tabular}{|c|c|c|c|c|c|c|}
\hline & \multicolumn{3}{|c|}{ Primiparous } & \multicolumn{3}{|c|}{ Multiparous } \\
\hline & $0 \mathrm{mg}$ & $4 \mathrm{mg}$ & $10 \mathrm{mg}$ & $0 \mathrm{mg}$ & $4 \mathrm{mg}$ & $10 \mathrm{mg}$ \\
\hline $\begin{array}{l}\text { No. of cows } \\
\text { CL }(\%),{ }^{1}\end{array}$ & 38 & 44 & 42 & 24 & 27 & 25 \\
\hline $\begin{array}{l}\text { d } 30 \text { to } 33 \mathrm{PP} \\
\text { Anovulatory }(\%)^{2}\end{array}$ & 76 & 64 & 71 & $67^{\mathrm{b}}$ & $44^{\mathrm{ab}}$ & $24^{\mathrm{a}}$ \\
\hline d 37 to $40 \mathrm{PP}$ & 13 & 18 & 24 & $13^{\mathrm{a}}$ & $26^{\mathrm{ab}}$ & $48^{\mathrm{b}}$ \\
\hline $\begin{array}{l}\text { No. of cows } \\
\text { Days to }\end{array}$ & 46 & 49 & 48 & 27 & 27 & 29 \\
\hline $\begin{array}{l}\text { first service } \\
(\mathrm{LSM} \pm \mathrm{SEM}) \\
\text { Days to } \\
\text { conception }^{3}\end{array}$ & $64.4 \pm 0.3$ & $62.5 \pm 0.3$ & $58.4 \pm 0.2$ & $62.0 \pm 0.5$ & $64.8 \pm 0.5$ & $64.8 \pm 0.5$ \\
\hline$(\mathrm{LSM} \pm \mathrm{SEM})$ & $115 \pm 8.0$ & $108 \pm 7.1$ & $105 \pm 7.9$ & $108 \pm 9.0^{\mathrm{AB}}$ & $136 \pm 12.7^{\mathrm{B}}$ & $100 \pm 11.2^{\mathrm{A}}$ \\
\hline
\end{tabular}




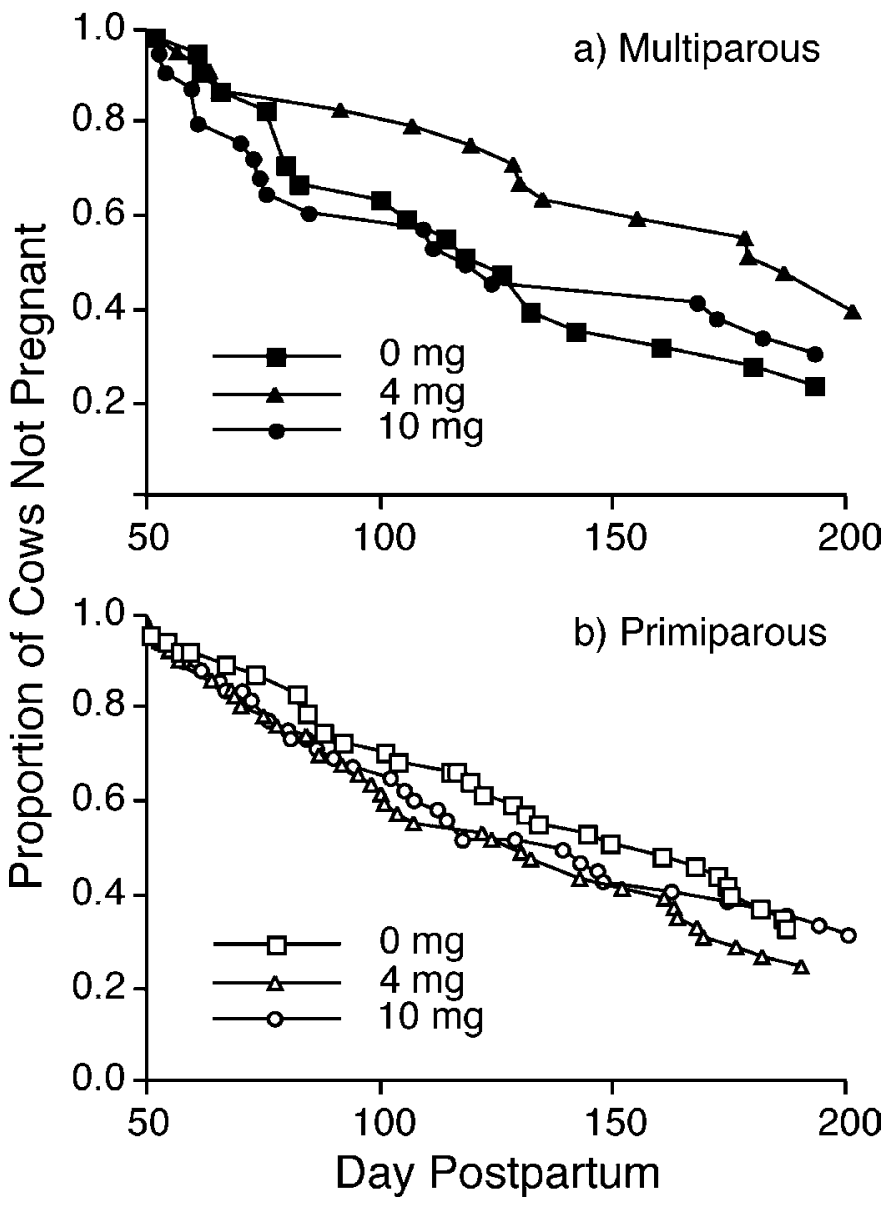

Figure 4. Survival curves of days to conception for multiparous and primiparous cows in experiment 2 . No differences $(P>0.10)$ were detected between treatments within each parity group.

\section{DISCUSSION}

Similar to the results of Vynckier et al. (1990), treatment with ECP resulted in a sustained elevation in circulating estradiol concentrations. Circulating estradiol concentrations after $10 \mathrm{mg}$ of ECP in the current study were about half the values reported by Vynckier et al. (1990), and this difference could be due to metabolic differences in lactating (our experiment) compared with nonlactating (their experiment) cows. We have previously reported very high liver blood flow and progesterone metabolism in lactating compared with nonlactating cows (Sangsritavong et al., 2002). The overall results provide insight into the mechanism by which ECP can delay the time to first ovulation and provide interesting although unexpected differences in the response to ECP treatment of primiparous compared with multiparous cows.

The first experiment demonstrated that ECP treatment could delay the time to first ovulation in lactating dairy cows by about $20 \mathrm{~d}$. This effect of ECP appeared to be due to suppression of circulating FSH and consequent inhibition of follicular wave initiation. This is consistent with the studies of Thundathil et al. (1998) showing that 0.5 or $1.0 \mathrm{mg}$ of ECP could alter follicular dynamics in cycling heifers. In all individual cows, the return of follicular waves corresponded closely to time of the first FSH surge following ECP treatment. As reported in other studies (Adams et al., 1992; Ginther et al., 1996), each follicular wave in individual cows was preceded by an FSH surge whether the wave occurred during anovulatory or ovulatory stages. There was no evidence in either experiment that treatment of early PP cows with ECP induced follicular cysts. This is consistent with a previous report of no increase in incidence of follicular cysts in lactating dairy cows treated with ECP (Fazeli et al., 1980). Thus, our data are consistent with any delay in time to first ovulation being due to a delay in follicular wave emergence due to suppression of FSH by ECP.

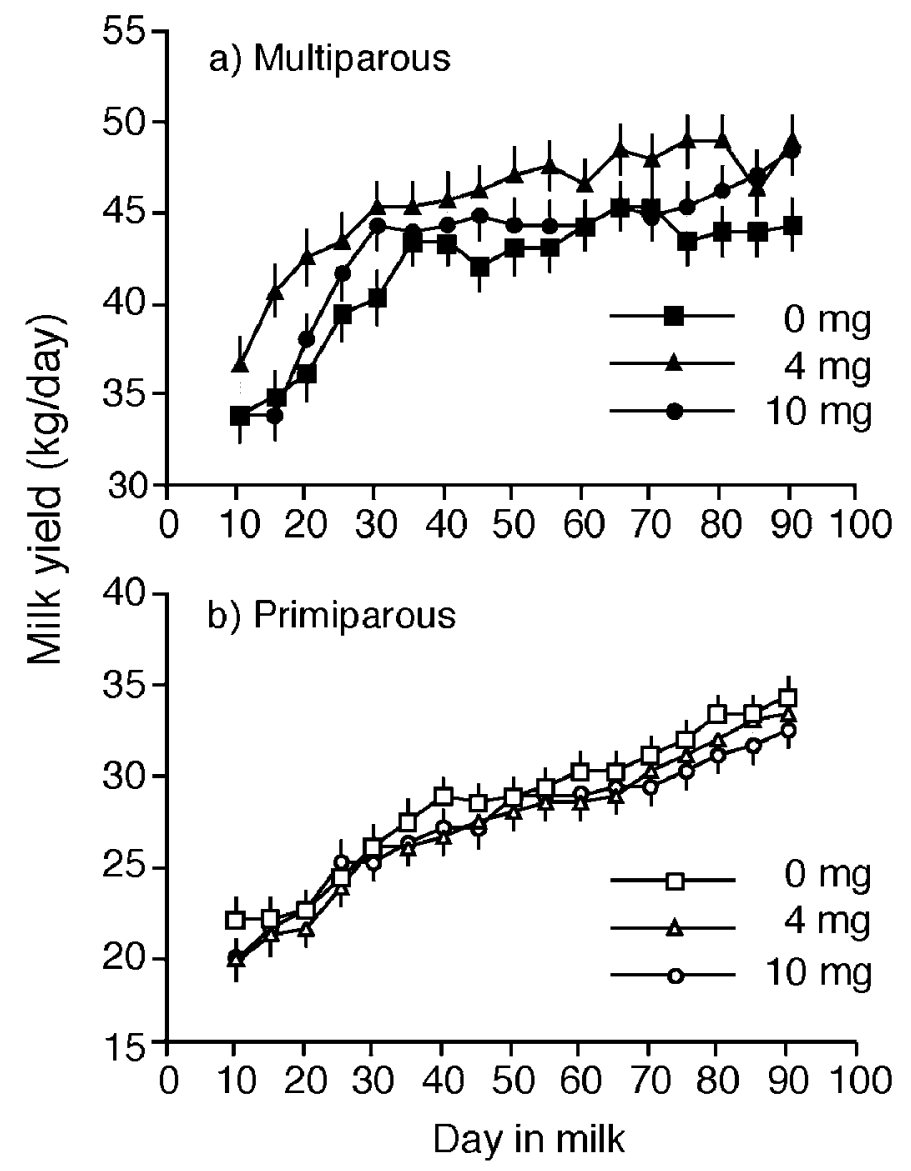

Figure 5. Daily milk yield profile (LSM \pm SEM) from 10 to $90 \mathrm{~d}$ PP for multiparous and primiparous cows left untreated $(0 \mathrm{mg})$ or treated with a single injection of 4 or $10 \mathrm{mg}$ of ECP on d 5 to $8 \mathrm{PP}$. 
Table 3. Least square means ( \pm SEM) of daily milk yield from d 10 to 90 postpartum (PP) from experiments 1 and 2. Dose of estradiol cypionate (ECP) administered in experiment $1 \mathrm{was} 10 \mathrm{mg}$.

\begin{tabular}{|c|c|c|c|c|}
\hline \multirow[b]{2}{*}{ Treatment } & \multicolumn{2}{|c|}{ Primiparous } & \multicolumn{2}{|c|}{ Multiparous } \\
\hline & $\mathrm{N}$ & $\begin{array}{l}\text { Milk yield } \\
\text { (kg/d) }\end{array}$ & $\mathrm{N}$ & $\begin{array}{l}\text { Milk yield } \\
\text { (kg/d) }\end{array}$ \\
\hline \multicolumn{5}{|c|}{ Experiment 1} \\
\hline Control & 7 & $29.11 \pm 0.89^{A}$ & 8 & $39.68 \pm 0.83$ \\
\hline ECP & 7 & $33.69 \pm 0.89^{\mathrm{B}}$ & 9 & $41.20 \pm 0.83$ \\
\hline \multicolumn{5}{|c|}{ Experiment 2} \\
\hline $0 \mathrm{mg}$ & 50 & $28.39 \pm 0.46$ & 26 & $40.78 \pm 0.62^{\mathrm{A}}$ \\
\hline $4 \mathrm{mg}$ & 50 & $28.52 \pm 0.45$ & 28 & $46.89 \pm 0.64^{\mathrm{C}}$ \\
\hline $10 \mathrm{mg}$ & 50 & $27.56 \pm 0.51$ & 28 & $43.72 \pm 0.61^{\mathrm{B}}$ \\
\hline
\end{tabular}

${ }_{\mathrm{A}, \mathrm{B}, \mathrm{C}}$ Within experiment, parity, means with different superscripts differ $(P<0.05)$.

In multiparous cows in experiment 2, ECP clearly increased the PP anovulatory interval. Nearly half of the multiparous cows had not yet ovulated by the second ultrasound examination ( 37 to $40 \mathrm{~d} \mathrm{PP}$ ) when they had been treated with $10 \mathrm{mg}$ of ECP; whereas only $13 \%$ of control multiparous cows were still anovulatory at $40 \mathrm{~d}$ PP. A particularly surprising finding was that ECP did not appear to increase the anovulatory interval in primiparous cows. We chose to evaluate the ovaries in experiment 2 near 30 and $40 \mathrm{~d}$ PP based on the ultrasound data obtained in experiment 1 . There appeared to be a greater number of cows ovulating earlier PP in experiment 2 than in experiment 1 . For example, at $d$ 30 there were $\sim 70 \%$ with a CL in experiment 2 , but only $38 \%$ of control cows had ovulated by d 30 in experiment 1 . It seems likely that any ECP-induced increase in the anovulatory interval is minimal in primiparous cows; although it cannot be ruled out that an ECPinduced delay in return to cyclicity may not have been detected due to lack of frequent ovarian examinations. The difference between primiparous and multiparous cows was totally unexpected, and we have been unable to find an adequate physiological explanation. Perhaps the suppression in FSH and delay in follicular wave emergence was reduced in primiparous cows due to greater metabolism of estradiol cypionate or reduced responsiveness of the hypothalamus/pituitary to estradiol in primiparous compared with multiparous cows. An understanding of the underlying reasons for the difference in ECP response would require experiments specifically focused on this hypothesis. Notwithstanding the delay in return to cyclicity, there was no difference in time to first service probably because of the aggressive reproductive management program, including timed AI, that was used on this dairy. One potential difference in reproduction was a slight increase in days to conception in the multiparous cows treated with 4 $\mathrm{mg}$ of ECP, but this represented only a trend $(P<0.10)$ and was not significant by the more appropriate survival curve analysis. In addition, there appears to be a decrease in conception rate in multiparous cows treated with $4 \mathrm{mg}$ of ECP. However, this result should not be considered definitive because of the low number of cows in the multiparous treatment groups. Other investigators have reported no effect of ECP on reproductive measures (Fazeli et al., 1980; Overton et al., 2001; Wagner et al., 2001). As previously noted (Wagner et al., 2001), the lack of an ECP effect when given to all cows in the early PP period does not rule out the possibility that specific health disorders may be effectively treated with ECP.

As was stated earlier, in experiment 1 there was some evidence to suggest a beneficial effect of ECP on average daily milk yield in both multiparous and primiparous cows, but confidence in these results was limited by low cow numbers and a high incidence of displaced abomasum in primiparous cows. Milk yield results from experiment 2 provide a much more reliable evaluation

Table 4. Results for specific health disorders and culling rates in experiment $2 .{ }^{1}$

\begin{tabular}{llllllll}
\hline & \multicolumn{3}{c}{ Primiparous } & & \multicolumn{3}{c}{ Multiparous } \\
\cline { 2 - 3 } & $0 \mathrm{mg}$ & $4 \mathrm{mg}$ & $10 \mathrm{mg}$ & & $0 \mathrm{mg}$ & $4 \mathrm{mg}$ & $10 \mathrm{mg}$ \\
\hline $\mathrm{N}$ & 54 & 52 & 54 & & 31 & 33 & 32 \\
Displaced abomasum (\%) & 19 & 21 & 13 & & 9 & 9 & 10 \\
Mastitis (\%) & $17^{\mathrm{A}}$ & $23^{\mathrm{AB}}$ & $33^{\mathrm{B}}$ & & 29 & 24 & 34 \\
Culling rate (\%) & 6 & 4 & 7 & & 16 & 18 & 13 \\
\hline
\end{tabular}

${ }_{\mathrm{A}, \mathrm{B}}$ Different superscripts within parity, row denotes significant difference $(P<0.10)$.

${ }^{1}$ Analysis includes all events recorded during initial $200 \mathrm{~d}$ of lactation. 
of the effect of ECP on milk production. In experiment 2 , there were significant effects of treatment and a treatment $\times$ parity interaction. In primiparous cows, treatment with 4 and $10 \mathrm{mg}$ of ECP had no effect on daily milk production. In contrast, multiparous cows had enhanced milk production in response to either 4 (13.0\% increase) or 10 (6.7\% increase) $\mathrm{mg}$ of ECP. We had hypothesized, before the experiment, that estradiol treatment might increase milk yield through a direct mitogenic effect on the mammary tissue. Our results are quite puzzling, however, as only multiparous cows had an ECP-induced increase in milk production, and even this effect did not have a dose-response profile. Perhaps our original thinking was overly simplistic, as the observed responses to estradiol are likely to be quite complex. Along with direct effects of estradiol on the cells of the mammary gland, there are likely to be effects of estrogens on lipid metabolism (Grummer et al., 1990) and secretion of growth hormone (Wehrenberg and Giustina, 1992; Hassan et al., 2001) or prolactin (Padmanabhan and Convey, 1979). The present experimental design did not allow us to differentiate the physiological explanations underlying the differences in response to ECP treatment. Clearly the unexpected experimental outcome from this study makes it imperative that this study be replicated in other dairies and under other experimental conditions. Repeating this research may help to provide the physiological explanation for the contrasting effects of ECP on primiparous and multiparous dairy cattle. In addition, consideration in future studies should be given to different $\mathrm{PP}$ treatment times. For example, treatment during the first day after calving may be more labor efficient and may provide greater benefit in treatment of early PP disorders.

In summary, a 10-mg dose of ECP was found to alter follicular growth and delay time to the first PP ovulation, particularly in multiparous cows. Convincing evidence for a positive effect of ECP on reproductive efficiency of dairy cattle has yet to be established. Lower conception among multiparous cows receiving $4 \mathrm{mg}$ of ECP is a potential concern. The effect of ECP treatment on milk yield was dependent on the ECP dose and the parity of the cows receiving treatment. It appears that a single ECP treatment does not consistently influence milk production in primiparous cows; whereas, a single ECP treatment enhanced milk production in multiparous cows.

\section{ACKNOWLEDGMENTS}

This work was supported by USDA grant \#2000-2276 and the Wisconsin Experiment Station. The authors thank Larson Acres for the use of their herd and facilities, as well as their assistance in conducting experi- ment 2. Roberto Sartori was supported by a fellowship from CAPES in Brazil. Ahmet Gümen was supported by a fellowship from the Ministry of National Education of Turkey.

\section{REFERENCES}

Adams, G. P., R. L. Matteri, J. P. Kastelic, J. H. Ko, and O. J. Ginther. 1992. Association between surges of follicle-stimulating hormone and the emergence of follicular waves in heifers. J. Reprod. Fert. 94:177-188.

Akers, R. M., T. B. McFadden, S. Purup, M. Vestergaard, K. Sejrsen, and A. V. Capuco. 2000. Local IGF-1 axis in peripubertal ruminant mammary development. J. Mammary Gland Biol. Neoplasia 5:43-51.

Athie, F., K. C. Bachman, H. H. Head, M. J. Hayen, and C. J. Wilcox. 1996. Estrogen administered at final milk removal accelerates involution of bovine mammary gland. J. Dairy Sci. 79:220-226.

Bolt, D. J., and R. Rollins. 1983. Development and application of a radioimmunoassay for bovine follicle-stimulating hormone. J. Anim. Sci. 56:146-154.

Bolt, D. J., V. Scott, and G. H. Kiracofe. 1990. Plasma LH and FSH after estradiol, norgestomet, and GnRH treatment in ovariectomized beef heifers. Anim. Reprod. Sci. 23:263-271.

Bulman, D. C., and G. E. Lamming. 1977. Cases of prolonged luteal activity in the non-pregnant dairy cow. Vet. Rec. 100:550-552.

Butler, W. R., R. W. Everett, and C. E. Coppock. 1981. The relationships between energy balance, milk production, and ovulation in postpartum Holstein cows. J. Anim. Sci. 53:742-748.

Butler, W. R., and R. D. Smith. 1989. Interrelationships between energy balance and post-partum reproductive function in dairy cattle. J. Dairy Sci. 72:767-783.

Crowe, M. A., P. Kelly, M. A. Driancourt, M. P. Boland, and J. F. Roche. 2000. Effects of follicle-stimulating hormone with and without luteinizing hormone on serum hormone concentrations, follicle growth, and intrafollicular estradiol and aromatase activity in gonadotropin-releasing hormone-immunized heifers. Biol. Reprod. 64: 368-374.

Darwash, A. O., G. E. Lamming, and J. A. Woolliams. 1997. The phenotypic association between the interval to post-partum ovulation and the traditional measures of fertility in dairy cattle. Anim. Reprod. Sci. 65:9-16.

Fazeli, M., L. Ball, and J. D. Olson. 1980. Comparison of treatment of pyometra with estradiol cypionate or cloprostenol followed by infusion or noninfusion with nitrofurazone. Theriogenology 14:339-347.

Ginther, O. J., K. Kot, L. J. Kulick, S. Martin, and M. C. Wiltbank. 1996. Relationships between FSH and ovarian follicular waves during the last 6 mo of pregnancy in cattle. J. Reprod. Fertil. 108:271-279.

Grummer, R. R., S. J. Bertics, D. W. Lacount, J. A. Snow, M. R. Dentine, and R. H. Stauffacher. 1990. Estrogen induction of fatty liver in dairy cattle. J. Dairy Sci. 73: 1537-1543.

Gümen A., R. Sartori, F.M.J. Costa, and M. C. Wiltbank. 2002. A GnRH/LH surge without subsequent progesterone exposure can induce development of follicular cysts. J. Dairy Sci. 85:43-50.

Hassan, H. A., W. J. Enright, H. A. Tucker, and R. A. Merkel. 2001. Estrogen and androgen elicit growth hormone release via dissimilar patterns of hypothalamic neuropeptide secretion. Steroids. 66:71-80.

Kesler, D. J., and H. A. Garverick. 1982. Ovarian cysts in dairy cattle: a review. J. Anim. Sci. 55:1147-1159.

Kulick, L. J., K. Kot, M. C. Wiltbank, and O. J. Ginther. 1999. Follicular and hormonal dynamics during the first follicular wave in heifers. Theriogenology 52:913-921.

Lucy, M. C., C. R. Staples, W. W. Thatcher, P.S. Erickson, R. M. Cleale, J. L. Firkins, J. H. Clark, M. R. Murphy, and B. O. Brodie. 1992. Influence of diet composition, dry matter intake, milk production, and energy balance on time of post-partum ovulation and fertility in dairy cows. Anim. Prod. 54:323-331. 
Opsomer, G., Y. T. Grohn, J. Hertl, M. Coryn, H. Deluyker, and A. de Kruif. 2000. Risk factors for postpartum ovarian dysfunction in high-producing dairy cows in Belgium: a field study. Theriogenology 53:841-857.

Overton, M. W., W. M. Sischo, and J. P. Reynolds. 2001. Effect of estradiol cypionate in postparturient dairy cattle at risk for metritis. Page 130 in Proc. Am. Assoc. Bovine Practitioners, Vancouver, BC. Am. Assoc. Bovine Practitioners, Rome, GA.

Padmanabhan V., and E. M. Convey. 1979. Estradiol-17 beta stimulates basal and thyrotropin-releasing hormone induced prolactin secretion by bovine pituitary cells in primary culture. Mol. Cell. Endocrinol. 14:103-112.

Pancarci, S. M., E. R. Jordan, C. A. Risco, M. J. Schouten, F. L. Lopes, F. Moreira, and W. W. Thatcher. 2002. Use of estradiol cypionate in a presynchronized timed artificial insemination program for lactating dairy cattle. J. Dairy Sci. 85:122-131.

Pursley, J. R., M. O. Mee, and M. C. Wiltbank. 1995. Synchronization of ovulation in dairy cows using $\mathrm{PGF}_{2 \alpha}$ and $\mathrm{GnRH}$. Theriogenology 44:915-923.

Rasmussen, F. E., M. C. Wiltbank, J. O. Christenson, and R. R. Grummer. 1996. Effects of fenprostalene and estradiol-17 $\beta$ benzoate on parturition and retained placenta in dairy cows and heifers. J. Dairy Sci. 79:227-234.

Sangsritavong, S., D. K. Combs, R. Sartori, and M. C. Wiltbank. 2002. High feed intake increases blood flow and metabolism of progesterone and estradiol- $17 \beta$ in dairy cattle. J. Dairy Science. 85:2831-2842.

Sartori, R., P. M. Fricke, J.C.P. Ferreiria, O. J. Ginther, and M. C. Wiltbank. 2001. Follicular deviation and acquisition of ovulatory capacity in bovine follicles. Biol. Reprod. 65:1383-1391.

SAS User's Guide: Statistics, Version 7. 1998. SAS Institute Inc., Cary, NC.
Smith, M.C.A., and J. M. Wallace. 1998. Influence of early post partum ovulation on the re-establishment of pregnancy in multiparous and primiparous dairy cattle. Reprod. Fertil. Dev. 10:207216

Thatcher, W. W., and C. J. Wilcox. 1973. Postpartum estrus as an indicator of reproductive status in the dairy cow. J. Dairy Sci. 56:608-610.

Thundathil, J. J. P. Kastelic, and R. J. Mapletoft. 1998. The effect of estradiol cypionate (ECP) on ovarian follicular development and ovulation in dairy cattle. Can. J. Vet. Res. 61:314-316.

Tucker, H. A. 2000. Hormones, mammary growth, and lactation: a 41-year perspective. J. Dairy Sci. 83:874-884.

Upham, L. 1997. Managing the postpartum cow. Western Dairyman 78:20-26.

Vynckier, L., M. Debackere, A. De Kruif, and M. Coryn. 1990. Plasma estradiol-17 (in the cow during induced estrus and after injection of estradiol-17( benzoate and estradiol-17( cypionate- a preliminary study. J. Vet. Pharmacol. Ther. 13:36-42.

Wagner, D. C., R. H. BonDurant, and W. M. Sischo. 2001. Reproductive effects of estradiol cypionate in postparturient dairy cows. JAVMA 219:220-223.

Wehrenberg, W. B., and A. Giustina. 1992. Basic counterpoint: mechanisms and pathways of gonadal steroid modulation of growth hormone secretion. Endocrine Reviews 13:299-308.

Wiltbank, M. C., A. Gümen, and R. Sartori. 2002. Physiological classification of anovulatory conditions in cattle. Theriogenology $57: 21-52$.

Woodward, T. L., J. L. Xie, and S. Z. Haslam. 1998. The role of stroma in modulating the proliferative response to ovarian hormones in the normal mammary gland. J. Mammary Gland Biol. Neoplasia 3:117-31. 